\title{
RUSSIAN CONSUL IVAN STEPANOVICH YASTREBOV ON THE POPULATION OF KOSOVO ${ }^{1}$
}

\section{Abstract:}

The article is devoted to the life and activities of a prominent Russian diplomat of the 19th century Ivan Yastrebov (1839-94). The author pays particular attention to the diplomat's written records evidencing the everyday life of the Serbs as well as the Albanians. The genesis of the Slav peoples in the Balkan Peninsula is also under examination.

\section{Keywords:}

Ivan Yastrebov, Russia, the Balkans, Serbia, Albania, Kosovo, ethno-genesis, everyday life.

АННОТАЦИЯ: П.А. ИСКЕНДЕРОВ. «РУССКИЙ КОНСУЛ ИвАН СТЕПАНОВИч ЯСТРЕБОВ О НАСЕЛЕНИИ КОСОВО».

Статья посвящена жизни и деятельности одного из ведущих российских дипломатов и специалистов по славянским народам Балканского полуострова И.С. Ястребова (1839-94). Особое внимание уделено его письменным свидетельствам об условиях жизни сербов и албанцев. В статье также рассматриваются вопросы этногенеза балканских славян.

\section{Ключевые слова:}

И.С. Ястребов, Россия, Балканы, Сербия, Албания, Косово, этногенез, повседневная жизнь.

$\mathrm{I}$ van Stepanovich Yastrebov (1839-94) was a Russian historian and ethnographer of the Balkans, a role he adopted as part of his diplomatic career. This began in the Asian department of the foreign ministry of the Russian empire, when he was 27 years old and a graduate of the Kazan Theological Academy. Yastrebov first trained at the Russian embassy in Constantinople, and the following year he became a secretary and dragoman (that is, a translator) of the Russian consulate in the Albanian city of Shkoder (Scutari) and soon headed the Russian delegation there. A little later, in 1870, Yastrebov took the post of vice consul in Prizren, an important political and cultural center of European Turkey, which, with good reason, was called the "Serbian Tsar'grad." Four years later he was appointed to the Greek city of Yanina, and then again found himself in Prizren as a Russian consul. The final stage of Yastrebov's diplomatic career was his position as Russian Consul General in Thessalonica.

Thanks to his linguistic talent (Yastrebov mastered Albanian, Arabic, Bulgarian, Greek, Serbian and Turkish) and a natural talent for observation, he be-

\footnotetext{
1 The work was carried out with the financial support of the RFBR (grant № 18-512-76004).
} 
came one of the foremost experts on the Balkans and amassed an enormous amount of knowledge about the living conditions of the peoples in this region. Yastrebov understood with clarity their aspirations and concerns, as well as the subtleties of interethnic and interfaith relationships among the local population. The rich historical and ethnographic material collected by Yastrebov formed the basis of his scientific works, primary among which was "The Customs and Songs of Turkish Serbs in Prizren, Ipeka, Morava and Dabre" (St. Petersburg, 1886; three years later the book was reprinted with addenda), "Addenda for the bistory of the Serbian Church. From the traveler of the record-writer" (Beograd, 1879) and "Old Serbia and Albania. Travel Notes" // Spomenik SKA XLI. Second

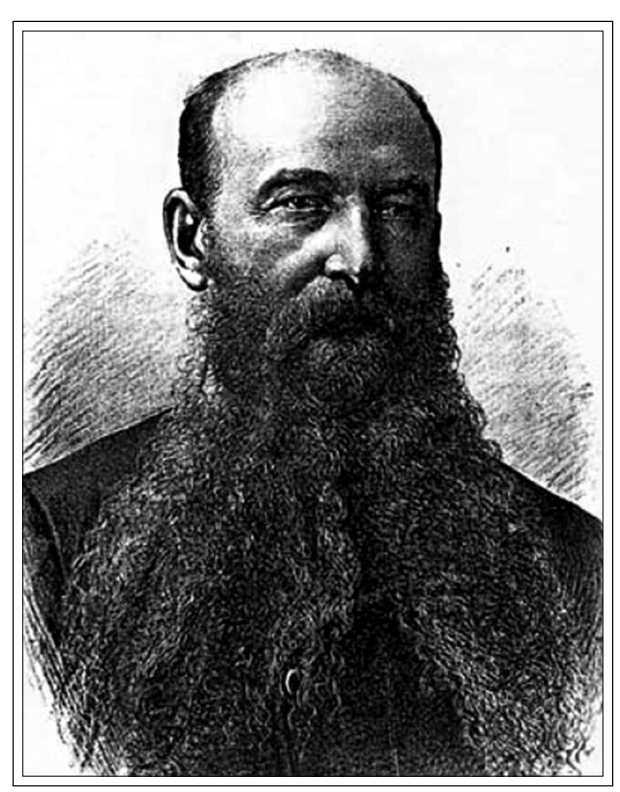

Diplomat, ethnographer

I.S. Yastrebov razred. (Beograd, 1904). In addition, he published his correspondence and articles in Serbian and Russian journals such as "The Orthodox Review", Novoye Vremya, "The News of St. Petersburg Slavic Charitable Society", Glasnik Srpskog Uchenog drushtva, etc.

In his works, Yastrebov mainly focused on the problem of the ethno-confessional composition of the population in the contentious areas already claimed by various Balkan countries and rulers. Above all, it concerned Kosovo, which in the Serbian historical tradition is called "Old Serbia." The Russian diplomat was the first to undertake a detailed analysis of the processes of Islamization and Albanization of the Orthodox Serbian population in this part of the Balkans. He emphasized that local Slavs who accepted Islam continued to observe Orthodox church holidays. Yastrebov wrote that in Prizren on the day of St George, $p o-$ turchentsy (Serbs who had converted to Islam) did not work and did not trade. This holiday in particular, he said, was the major holiday of Serbs in Kosovo: for both Orthodox and Muslims.

Yastrebov stated that for Serbs there is no more important oath than an oath to the saint considered to be the patron saint of their ancestors and their family's descendants. Even the most destitute Serbs prepared for their patron saint's day with special diligence and reverence, celebrating him very solemnly. In his words, the Serbs call this day "Krsno Ime" - i.e., "The name of the cross," "Sveti" - i.e. "Holy" or simply "Glory."

During his many years in Old Serbia and Albania, Yastrebov observed a multitude of customs and witnessed how they were performed at home and in gath- 
erings. The celebration of the above-mentioned holiday made the strongest impression on him. In addition, he wrote that the Serbs celebrated it not just in Serbia itself, but also wherever they lived: in Austria, Hungary, Bosnia, Montenegro, on the Kosovo field, on the Morava, in the Prizren region, as well as in the Skoplen, Veles, Prilep, Bitola and Ohrid districts, Dabar, and in the vicinity of Tetovo. Yastrebov testified that all residents within these areas, excluding the Aromanians and Hellenized Walachians, spoke the Slavic-Serbian dialect and faithfully observed this custom, which had acquired the status of a religious rite.

In Yastrebov's estimation, the process of the Islamization of the Serbs began at the very beginning of the 19th century, when the representatives of the older generation in the Opol'e region communicated primarily only in Serbian. With respect to the district of Lyuma, located on the road from Prizren (Kosovo) to Central Albania, Yastrebov wrote in the 1870s that about half a century previously the Lyumlian fathers spoke Serbian. According to his statement, the names of the villages near Lyuma and Opol'e were Serbian.

He observed that Kosovo Serbs sometimes had two names, one Christian and the other Muslim. In the Opol'e region, there were few "real" Albanians, i.e., people from the central Albanian regions of Mat and Dukadzhin. The majority of the population were already Albanized Serbs. Yastrebov attested that about three decades earlier people usually lit a ritual bonfire in Opol'e on Orthodox Christmas Eve. In the village of Brod-u-Gori, according to the stories of local inhabitants,

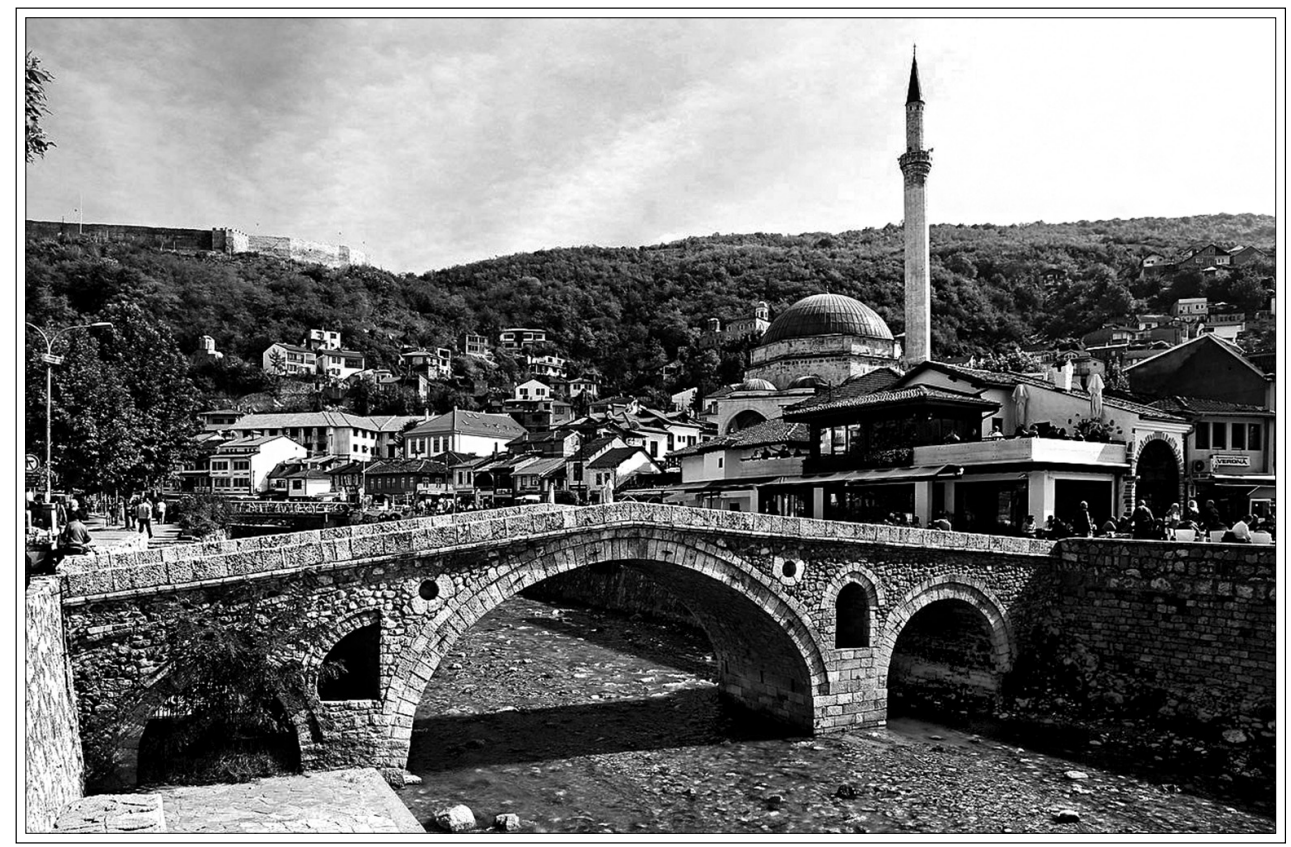

View of the city of Prizren, where I.S. Yastrebov worked as a Russian consul 
there used to be three churches, and local elders recalled how, as children, they used to go to the Church of St Nicholas, and their parents would put candles on their ancestors' graves at the local Orthodox cemetery.

Yastrebov called the Islamized and Albanianized Serbs "Arnautashes" and believed that they differed from the "true" Albanians of "Arnauts": natives of the western regions of the Balkans. In pointing out the differences, he wrote that the Arnautashes barely knew what honor was, they were deceitful and did not keep their word. The "real" Arnautes, however, behaved differently: they were faithful to their word, would not betray anyone and knew what honesty was. While the Arnautashes toadied up to everyone, and their behavior towards the authorities was vile, hypocritical and full of pretense, the Arnautes in such circumstances behaved nobly and with dignity.

It was Yastrebov who first introduced into Russian diplomatic language and scientific use such ethnic definitions as the "internal" Serbs and Bulgarians.

The process of the Islamization of the local Serbs gave rise to complex and painful feelings in self-identification and everyday behavior. The Orthodox, he observed, tried to preserve the Serbian language until they converted to Islam. After that, the local Serbs would be ashamed to speak their native language, lest they be called a poturchenets. For this reason, such Serbs began to hate their native Serbian language. According to Yastrebov, in the Debar region, east of Korab and in the foothills of the Sharr Mountains, there were about 30 villages inhabited by Orthodox Christians who bore Serbian names but spoke Albanian. According to him, only in the village of Skurdina did the inhabitants, which included Muslims, speak Slavic Serbian.

In his work Yastrebov also paid a great deal of attention to the customs and everyday life of the people of Kosovo. Per his observation, in such relatively large cities as Pech, Prizren, Prishtina and Dzhakovitsa, the local population had little that unified them. Christians and Muslims, he said, led reclusive lives, especially the women.

The writings of I. S. Yastrebov also contain information that allows us to assess the rate of Islamization of the Serbian population of Kosovo. Thus, in the area of the famous Serbian Orthodox monastery of Dechany, in the last twenty years of the 19th century the number of houses inhabited by Orthodox Serbs decreased by more than three times: from 165 to 50 . The Russian diplomat testified that it was only by a miracle that the church survived and was never converted into a mosque.

Translated by Ksenia Melchakova

\section{BIBLIOGRAPHY}

Bovan V. Jastrebov u Prizrenu. Beograd, 1983.

Terzich S. Russkii konsul I.S. Iastrebov o Staroi Serbii // Iz istorii Serbii i russko-serbskikh sviazei. $1812-1912-2012$. Moskva, 2014. 


\section{ILLUSTRATIONS}

1. Diplomat, ethnographer I.S. Yastrebov.

2. View of Shkodra, the city where the Russian consulate I.S. Yastrebov worked as a translator, secretary, and then consul.

3. Orthodox Serbian monastery Visoki Dechany.

4. View of Prizren, the city where I.S. Yastrebov worked as a Russian consul.

5. The Cover of the book by I.S. Yastrebov "Customs and songs of the Turkish Serbs. The second edition, supplemented by their prose." St. Petersburg, 1889.

6. View of Thessalonica, where I.S.Yastrebov served as the Russian Consul General several years until his death. 